\title{
Economic Development Impacts of Colorado's First 1,000 Megawatts of Wind Energy
}

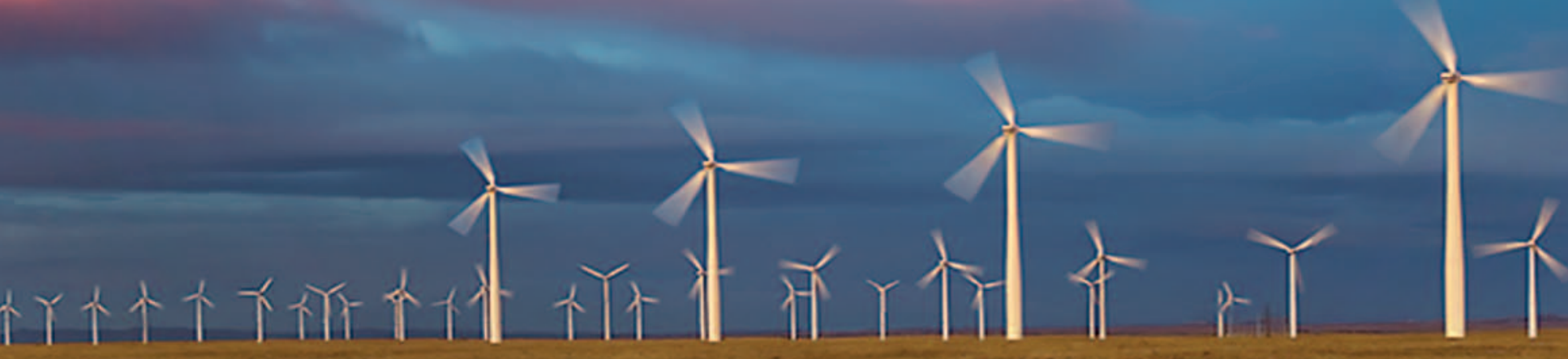

Jenny Hager Photography/PIX15990

This fact sheet summarizes the findings of a report authored by Sandra Reategui and Suzanne Tegen of the National Renewable Energy Laboratory (NREL). The full report, including a detailed methodology section, is available as a PDF download from NREL's publications database at www.nrel.gov/docs/fy08osti/43505.pdf

According to the American Wind Energy Association's (AWEA's) Annual Rankings Report, Colorado is the second-fastest-growing wind energy producer in the United States (Texas is first). A confluence of events ignited soaring growth in the number of Colorado's wind power installations in recent years, from 291 megawatts (MW) of capacity in 2006 to 1,067 MW (capacity) in 2007.

Analyzing the economic impact of Colorado's first 1,000 MW of wind energy development not only provides a summary of jobs, land lease payments, and other revenue, but it also provides a sense of the economic development opportunities associated with other new wind project scenarios, including the U.S. Department of Energy's 20\% Wind Energy by 2030 scenario. The analysis can be used by interested parties in other states as an example of the potential economic impacts if they were to adopt 1,000 MW of wind power development.

\section{Economic Development Impacts in Colorado}

In November 2004, Colorado voters passed Amendment 37, which created a 10\% Renewable Portfolio Standard (RPS) by 2015. The impacts to Colorado citizens of this increased renewable energy production quickly became apparent, and in 2007 new legislation doubling the RPS passed with bipartisan support.

Large utility-scale wind projects provide new jobs nationwide, but especially in rural communities where there is a need for job retention and diversification. Many rural areas have experienced economic declines intensified by local populations migrating to urban areas for more opportunities. Wind power projects generate tax revenues that are used to improve schools and other public services, which in turn improve the quality of life in rural areas. Local landowners also receive extra income in the form of land lease payments from wind turbines located on their land. New wind power installations also offer other benefits, such as use tax generation, sales tax generation, transmission line impacts, water savings, price stability, and environmental benefits.

To quantify these impacts to Colorado, NREL researchers used the Jobs and Economic Development Impact (JEDI) model. The model calculates the number of jobs and the amount of money spent on salaries and economic activities generated in a specific location from the construction and operation of a wind power plant. The JEDI Wind Energy Model can be downloaded at www.nrel.gov/analysis/jedi. A detailed description of JEDI and the methodology used in the analysis can be found in the report.

The NREL researchers conducted extensive interviews with developers, lawyers, county commissioners, stakeholders, and other industry experts. Data gathered from interviews included construction cost, operation and maintenance cost, percentage of goods and services acquired in-state, job generation during the construction period, job generation during the operating period, land lease payments, tax information, payroll parameters, and cost breakdown of different categories based on project cost percentages. The JEDI model was adjusted to reflect verified data obtained from interviews. 
Individual economic impacts were then aggregated to reflect combined impacts from 1,000 MW.

According to the analysis performed by Reategui and Tegen of NREL, $1,000 \mathrm{MW}$ of wind power development in Colorado:

- Generates electricity to power more than 248,000 homes $(11.8 \%$ of Colorado housing units in 20061)

- Generated approximately 1,700 full-time-equivalent jobs* during construction periods with a total payroll of more than $\$ 70$ million (2008 dollars)

- Supports approximately 300 permanent jobs* in rural Colorado areas with a total annual payroll of more than \$14 million (2008 dollars)

- Generated \$226 million in economic activities from the construction period (2008 dollars)

- Generates \$35 million in annual local economic activities (2008 dollars)

- Generates more than $\$ 4$ million in annual property taxes (2008 dollars)

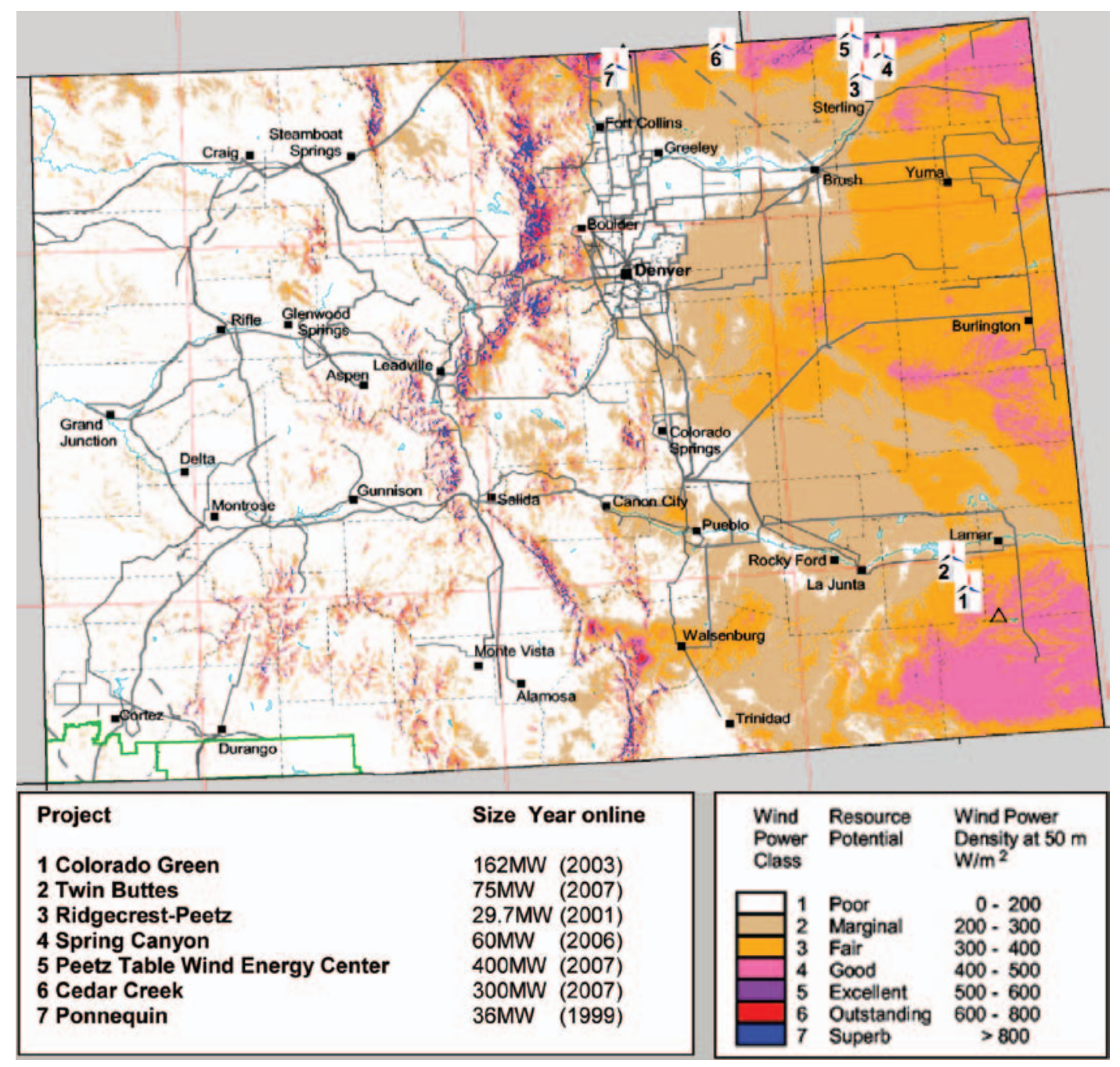

Current Colorado Wind Project Locations

3 Renewable Resource Generation Development Areas Task Force. (2007). Connecting Colorado's Renewable Resources to the Markets. Report of the Colorado Senate Bill 07-091. December, 2007.

\section{The Future of Colorado Wind Projects}

In terms of resource potential, Colorado currently ranks 11th out of 50 states$^{2}$. A report of the Task Force on Renewable Resource Generation Development Areas has identified eight wind generation development areas in Colorado, with the combined potential to generate $96,000 \mathrm{MW}$ or 96 gigawatts (GW) of capacity ${ }^{3}$.

\section{References}

1 According to the U.S. Census Bureau.

2 American Wind Energy Association (2008). U.S. Wind Energy

Projects-Colorado (As of January 16, 2008). Retrieved

January 21, 2008. http://www.awealorg/projects. Projects.

aspx?s=Colorado
* Direct, indirect, and induced.

\section{For More Information, Contact:}

Sandra Reategui, Sandra_Reategui@nrel.gov

Suzanne Tegen, Suzanne_Tegen@nrel.gov

Wind Powering America

National Renewable Energy Laboratory

1617 Cole Blvd. MS3811

Golden, C0 80401

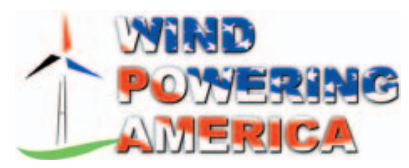

January 2009・DOE/G0-102009-2687 www.windpoweringamerica.gov 